\title{
sciendo
}

DOI. 10.1515/anpm-2018-0010

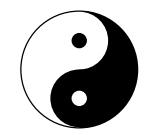

\section{UZBEK HEAD ORNAMENTS FROM THE COLLECTION OF THE NÁPRSTEK MUSEUM}

\author{
Tereza Hejzlarová ${ }^{1}$
}

\begin{abstract}
Jewellery occupied an important place in the various life stages of Central Asian women. Individual jewels that formed sets depending on which parts of the body they were worn on had in a steady form and a particular meaning in the past. Most of the items of jewellery were designed to decorate the upper half of the body, and among the most numerous sets there was a set of head ornaments. These were mainly various types of diadems, paired and individual pendants that were attached to the headdress or to the hair and, last but not least, earrings of various shapes and sizes. The collections of the Náprstek Museum of Asian, African and American Cultures feature a set of head ornaments from Uzbekistan dating back to the late $19^{\text {th }}$ and early $20^{\text {th }}$ century when the jeweller's creations of the region were still of high quality. The set is represented by jewellery of three local styles - Samarkand, Bukhara and Tashkent.
\end{abstract}

KEY WORDS: head ornaments - Uzbeks - Tajiks - jewellery - Náprstek Museum - museum collections

\section{Introduction}

Jewellery played a very important role in the lives of Central Asian girls and women. They fulfilled not only an aesthetic but, above all, a magical function. The quantity and types of ornaments also determined the social status of the wearer. Women were adorned with jewellery not only during ceremonial occasions but also on weekdays. Most importantly, however, they were used at the time of the wedding.

The set of jewels was gradually changing, depending on age and social status. After the birth of her first descendant, the young mother slowly reduced the number of jewels and wore a larger set only on holidays and festive occasions. Around the fortieth year of age, it was no longer appropriate for women to wear a larger number of ornaments,

1 Contact: Department of Asian Studies, Faculty of Arts, Palacký University Olomouc, Czech Republic; email: alabaj@email.cz. The work was supported from European Regional Development Fund-Project

"Sinophone Borderlands - Interaction at the Edges" CZ.02.1.01/0.0/0.0/16_019/0000791.

This work is licensed under the Creative Commons Attribution-Noncommercial-No Devivs 3.0 License 
only rings and earrings of simpler forms were permissible. At certain stages of life, jewellery was also removed completely. In some areas, such periods included forty days after the birth of the first child. The main reason for refraining from wearing jewellery was, however, the death of the husband or the death of the woman herself. The period without jewellery in the event of widowhood could take up to one year after the death of the husband, and jewellery could not be worn not only by the widow, but also by close relatives. Although according to Sharia, or Islamic law, the body should be clean and unburdened before the funeral, deceased women in many cases were buried with their earrings and men with their rings (Тохтабаева 1991: 10, Фахретдинова 1988: 159).

In each area, alongside common features, local differences can be found in jewellery sets, which were reflected in the form, way of decorating or prioritizing one or another technique. For example, many common features can be identified in the filigree jewellery of Samarkand, Tashkent, and Bukhara. It is especially jewels from the Khwarezm Region, to which original, ancient forms are attributed, that are distinguished by their peculiarities. In Tajikistan, the cities of Khujand and Ura-Tyube in the north of the country belonged to the most important jewellery centres. It is the jewellery of northern Tajikistan that had many common features with artworks of the settled population of Uzbekistan, while southern Tajikistan jewels are close to artworks of semi-nomadic Uzbeks (Чвыр 1977: 38).

\section{Collection of the Náprstek Museum}

In the Central Asia Collection of the Náprstek Museum, there is a set of head ornaments from Uzbekistan that represents the jewellery production of settled Uzbeks and Tajiks from the late $19^{\text {th }}$ to the early $20^{\text {th }}$ century.

The collection includes a mokhi tillo headdress ornament (Inv. No. 40408), and a tilla bargak diadem (Inv. No. 40410), representing the Samarkand jeweller's production from the late $19^{\text {th }}$ and early $20^{\text {th }}$ century. These pieces of jewellery come from the collection of Czech geographer Emanuel Fait (1854-1929)², who in 1902 resided in the Uzbek cities of Bukhara, Samarkand, Tashkent and later in Kokand and Andijan in the Fergana Valley (Hejzlarová - Pospíšilová 2012: 13). His collections represent some of the oldest items that made a significant contribution to the formation of the Central Asia Collection of the Náprstek Museum.

The Samarkand jewellery style is also represented by isirga earrings (Inv. No. 43816 $\mathrm{ab}$ ), and khalka earrings (Inv. Nos. 21229, 21230) dated to the late $19^{\text {th }}$ and early $20^{\text {th }}$ century, acquired in 1891 and 1902 by Václav Kračmer, a comprehensive school teacher in the Russian service in the city of Verny.

In 1883, the Museum was donated a small set of pendants (Inv. Nos. A 28934/1-3) by Emanuel Meergans, an engineer in Russian services in Turkmen city of Merv. ${ }^{3}$ The set, which contains one of the major components of the set of head ornaments, a gajak pendant, illustrates the unique work of the Tashkent jewellers from the late $19^{\text {th }}$ century.

The Bukhara or Tashkent styles are represented by richly decorated khalka earrings (Inv. No. A $18437 \mathrm{ab}$ ) from the early $20^{\text {th }}$ century. The museum bought them in the 1980 s.

The Bukhara jeweller's production is represented by another pair of khalka earrings

2 For more information about E. Fait see: Скреминская 2017.

3 There is no more information available to the originators V. Kračmer and E. Meergans. 
(Inv. No. A $15424 \mathrm{ab}$ ), from the late $19^{\text {th }}$ and early $20^{\text {th }}$ century, which the Museum also acquired by purchase in 1980s.

\section{Mokhi tillo}

Mokhi tillo was a headdress ornament typically in the shape of a half-moon with raised curved ends, between which there was the motif of a bud or a rhombus. The lower part was decorated with a garland of chains with beads. In the upper part, three chains were attached connected together by a hook that secured the mokhi tillo to the headdress.

Various jewellery techniques were used to make the mokhi tillo. The most famous was filigree metalwork, consisting of very small circles, which is typical of the Samarkand jewellery style. Around the circumference of the jewel, small turquoises were also inserted into rings, or the filigree base was further adorned with small flowers decorated with stamping. Such a mokhi tillo had an openwork appearance and looked very gentle and airy [Pl. 1].

Bukhara jewellers made this ornament usually from a thin gold or gilded silver plank decorated with stamped geometric ornaments and precious stones or glass stones. The back side was decorated with a fine plant pattern of islimi using a stamping technique. Chains in the lower part were decorated with small pearls, ruby and beryl beads, as well as rings and spirals made using the granulation technique (Фахретдинова 1988: 94).

As far as the names of this jewel are concerned, we can encounter several local ones - mokhi tillo, at tuegi and bibishokh (bibishok, bibishak). The name mokhi tillo - "golden moon" refers to the astral cult. The Moon (Luna) has traditionally been associated with the woman's principle, with a crescent symbolizing the beginning of a new life cycle and being an attribute of the fertile mother goddess (Гюль 2003; Фахретдинова 1988: 96). The name at tuegi - "horse hoof" testifies to a widespread belief in the magical power of the horse hoof, more precisely its imprints. In many parts of Central Asia, stones with "horse hoofprints" are worshiped, which are either considered to be hoofprints of Saint Ali's horse or hoofprints of an elite horse. Childless women go to prey to these stones with horse hoofprints, stroke them with a hand that they then put on their forehead (Hejzlarová 2007: 93-94). In this context, it is worth mentioning that the mokhi tillo was worn mostly attached to the headdress in the middle of the forehead. Some scholars consider it a paired ornament that was hanged on the sides of the head, or a three-piece set (one on the forehead, two on the sides) (Фахретдинова 1988: 94). The last name bibishokh is usually understood to be the "mother's horns" (bibi-mother, shokh - horns). In Central Asia, stylized horns can be found on women's headdress, for example, among the Kipchaks, who in the $11^{\text {th }}$ and $12^{\text {th }}$ centuries used to build statues of women with birds in their hands and a horn-like headdress. In the $19^{\text {th }}$ century, the headdress of the Karluks in the Kashkadarya Region was called shokh bosh - horned head (Фахретдинова 1988: 96). ${ }^{4}$ The motif of horns, especially those of the ram, was widely used in Central Asia's applied art. The ram (kochkor, kuchkor) was attributed a powerful protective meaning. A ram's skull was fixed to the door of the house or placed in orchards. Families where sons often died gave the newborn the name Kuchkor, which was believed to defeat evil forces and protect the child. The Khwarezmian

4 A particularly distinctive form of "horned" headwear called ever (horns) is worn by married women of the Khalkha Mongols. 
Uzbeks often kept a ram in the house to protect themselves from evil spirits as they believed that all evil forces would first be trapped in the ram's horns where they would lose their power. Besides, rams served as sacrificial animals, and their paddle bone was mainly used by the nomads for divination. In Central Asia, the ram was also referred to as rahmoni, originating from the Arabic word ar-Rahman - "Merciful", which is one of God's names in Islam (Богословская - Певтеева 2006: 48).

Some scholars see the motif of a little bird in the mokhi tillo. On rare occasions, we can, albeit not very clearly, identify two little bird heads placed on the sides of the central motif of the bud. In another case, the central motif is formed by two connected bird heads and the bent ends of the crescent moon represent a bifurcated bird's tail. The presumption of the original bird's motif is supported by archaeological finds of jewellery in Central Asia where there are two bird heads depicted on it. ${ }^{5}$

\section{Tilla bargak}

Uzbek and Tajik women were particularly fond of various types of finely-worked diadems, including tilla bargak (golden leaf) ${ }^{6}$, which was a very widespread adornment especially at the beginning of the $20^{\text {th }}$ century (Сычева 1984: 23). This diadem was usually stitched to a strip of cloth, such as velvet or satin, but also fur (Фахретдинова 1988: 104). The best-known tilla bargak originated from Samarkand and Tashkent and consisted of a series of thirteen to fifteen square gold-plated silver plates with an embossed decoration of rosettes [P1. 2]. The lower part was lined with a number of small movable pendants in the shape of rhombuses and petals patterned using a stamping technique. Plates and pendants were mostly decorated with turquoise and coral beads. Some tilla bargak were even more elaborate. Above the central rosette and some others, plates of more complex forms with a distinctive oval-shaped glass stone were attached, surrounded by a series of tiny turquoises. On the back of the plates there were collets loaded with bundles of bird feathers. Tilla bargak was worn either separately or together with a crown tilla kosh made in the same style. Tilla bargak by Bukhara jewellers was different, in particular owing to the central plate that was larger in size, most often in the form of a star-shaped rosette. On the other square plates, a trifoliated rosette motif of the geometrized form was embossed. This Bukhara type of tilla bargak formed a set together with the tavk necklace and gajak pendants. The earliest forms of this diadem are thought to be the Khwarazmian diadems manglay tuzi and osma tuzi, which were more massive and more embellished.

The tilla bargak set also contained pendants whose name was not preserved [Pl. 3, left]. These pendants consist of a square plate with a stamped decoration, embellished in the centre with coloured glass and small turquoises. In the lower part, and sometimes on the sides, movable short chains with pearls were attached. In addition, the lower part was originally decorated with bird feathers (Фахретдинова 1988: 114).

Using bird feathers as a jewellery item was not just an aesthetic matter. The belief in the sacral power of some species of birds was very widespread in Central Asia. Settled inhabitants regarded the cock, the pheasant and the peacock as sacred birds (Наршахи

\footnotetext{
5 For example, the bronze jewellery found in the Khwarezm Region with a rendering of two swan heads, dated to the $4^{\text {th }}-3^{\text {rd }}$ century BCE (Фахретдинова 1988: 95).

6 The Tajiks also called it kasaba, or simply bargak.
} 
1897; Борозна 1975: 283). ${ }^{7}$ They were related to the sun and associated with fertility. A portrayal of birds on jewellery guaranteed the bride's happiness in family life. Feathers as well as claws had magical properties and were often attached to head ornaments, but they also adorned women's and children's caps. The Uzbek Durmens of the Tashkent Region kept a pheasant in the house in the event that children often died in their family. The pheasant was believed to protect against various diseases. Pheasant feathers were attached to children>s caps as a protective amulet (Борозна 1975: 283294).

\section{Gajak}

Gajak by Tashkent and Samarkand jewellers were a popular decoration of the Uzbeks and Tajiks from the early $19^{\text {th }}$ to the early $20^{\text {th }}$ century (Сычева 1984: 21). Gajak (kajak) is a silver almond-shaped plate, the elongated end of which forms a volute [Pl. 3, right]. Both ends of the jewel were usually equipped with a chain, connected by a hook at the end, by which the gajak was attached to the headdress or to the hair in the temple area. In this way, the horizontal position of the jewel was achieved. At other times, the gajak was fastened at both ends by a double, spirally curled wire, which made it possible to hang it on the ear. The surface of the jewellery was adorned with larger, coloured roundshaped glasses, trimmed with tiny turquoises. The toothed setting gave the red, green, and blue glass stones the shape of a star. The lower part of the jewel was decorated with chains with metal beads, coral beads or small pearls. On the back, there were loops for attaching bird feathers. The gajak was usually decorated with a crimped duck feather. The Tajiks from the Asht Region decorated it with peacock feathers of different colours (Чвыр 1977: 47).

In Tashkent and Samarkand, the gajak belonged to a set together with the tilla kosh coronet. Around 1915, this item of jewellery ceased to be worn in Tashkent, and the jewellers there began to remake it into a brooch (tunagich) (Фахретдинова 1988: 113).

The word gajak has more meanings: it can mean a lock, a curl, a duck's feather or a plant sprout. Gajak is most commonly associated with a lock, a curl, especially because of its being worn in the temple area. Curls on the temples were believed to have a magical protective meaning. In the $19^{\text {th }}$ century, for example, parents let their long-awaited children's strands grow longer on the temples, just to be cut later and used as a sacrifice for cereal ceremonies. The protective significance of hair is evidenced by the habit of keeping the baby's first cut hair in a silver amulet case (tumar). If a silver tumar was not available, the mother stitched the baby's hair into a triangle-cut fabric, ${ }^{8}$ which was then attached to the back of the baby's shirt or to the baby's cap. A poetic evidence of using hair as a protective amulet can also be found in a poem by Boborahim Mashrab, ${ }^{9}$ who writes: An amulet made of my loved one's curly hair is tied to my nape (Дивана-и-Машраб 1915: 177). ${ }^{10}$

Due to its form and being decorated with bird feathers, the gajak is also associated

7 In nomadic inhabitants, it was predominantly the horned owl, eagle, falcon and hawk. Cocks or hens were also used as sacrificial animals in shamanic rituals of settled residents.

8 Amulet cases were very often triangular.

9 Boborahim Mashrab, a poet and supporter of the Naqshbandi Sufi Order, was probably born in Namangan, Uzbekistan, in 1657 and died in 1711 in Balkh, Afghanistan. It is considered to be a classic writer of Uzbek literature.

${ }^{10}$ Own translation. 
with the shape of a bird. In some specimens, the bird figure is more distinct, in others almost unrecognizable. The bird's body is represented by the almond-shaped part, the curved slim part being the neck, ending with the head with the beak. The end part is mostly decorated with a glass stone representing the eye. In some cases, the almondshaped part is further decorated with filigree arranged in a shape that resembles feathers of water birds (Фахретдинова 1988: 113).

As for the plant kingdom, the gajak resembles the almond motif (bodom), which was one of the most widespread in Uzbek and Tajik applied arts. The almond motif was primarily an important protective amulet against the she-demon albasty ${ }^{11}$. However, some researchers think that it was originally a bird motif, from which the almond motif developed later in the process of stylization. ${ }^{12}$

\section{Earrings}

The earrings, commonly called isirga, had multiple forms ranging from very simple and tiny ones to those richly embellished with plenty of pendants. The naming of earrings was based primarily on their shape (for example, khalka - circle), the number of pendants (for example, uch ayak $k^{13}$ - with three pendants, besh ayak - with five pendants), but also on the processing technique or material from which they were made. Wealthy women demonstrated their wealth by wearing several earrings at the same time. Heavier earrings were thus sewn on a ribbon that was then laid over the head.

Earrings were also a symbol of slavery. In the $19^{\text {th }}$ century, purchased slaves were branded with a silver ring in Bukhara, men in the right ear, women in the nasal septum (Фахретдинова 1988: 118). Despite this fact, the belief in their protective power prevailed. When a child was born into a childless family after a long time, families with a lot of children collected fragments of silver jewellery from which an earring was made that the baby wore until its wedding (Фахретдинова 1988: 118). An interesting habit was also associated with earrings. If a woman lost one of her earrings, she was not allowed to ask a jeweller to make only one of the pair since it was believed that if the jeweller did not make a pair, her wife would leave him, and if he happened to be single, he would not get married (Фахретдинова 1988: 124).

Popular and widespread earrings included intricately yet gently made earrings generally called khalka. The upper part was formed by a ring mostly filled with a filigree ornament in the form of a lotus flower, a tulip, a butterfly or a fan, connected to rich pendants from chains and beads made of silver, red coral, coloured glass or small pearls [P1. 5]. A golden crescent moon with embedded stones of red and green was attached to the lower part of the ring in the golden Bukhara earrings intended for aristocracy. The number of chain pendants ranged from three to seven; they were decorated with beads made of gold, beryl, ruby and small pearls, which were interlaced with small rings

${ }^{11}$ Albasty appeared most often in the form of a woman with long yellow hair and long breasts draped over her shoulders. She was dangerous to young men and especially to pregnant women. The shedemon could also make women infertile by binding their reproductive organs. She had power over the heart, liver, and lungs, which she stole from mothers and newborns and carried them to water. If she managed to wash the viscera, the mother and the child died. A child could also die if it drank from her breast. If albasty threw her breast on a person, they then fell unconscious and severely ill.

${ }^{12}$ Григориев, Г. Тус-тупи. Искусство, 1937: 121-143, no. 1. Retrieved from: Чепелевецкая 1961: 72.

${ }^{13}$ Literally "three-legged". 
created using the granulation technique. Sometimes, these earrings were supplemented with enamel-covered beads on which stamped leaves and rosettes were attached. However, this technique did not have a wide spread (Фахретдинова 1988: 120).

In Tashkent and Bukhara variants of this type of earrings intended for middle-class women, the central motif was a gold-plated ring, reminiscent of the Sun with beams, whose periphery was richly decorated particularly with granulation [Pl. 6]. In another variant of the Tashkent earrings, blue, red and white opaque glasses or wax was inserted into the lower butterfly-shaped part of the circle, using a stained-glass-like technique (Фахретдинова 1988: 120).

In addition to beads, the khalka earrings were decorated with one or three cupolas [P1.4], mostly decorated with motifs of triangles and rhombuses created using stamping or granulation techniques, or with a series of tiny turquoises. On the cupola, chains of silver beads or coral beads were hanged, ending with silver stamped grains, which were meant to symbolize barley grains - a symbol of fertility. The Tajiks usually called such earrings guz khalka (Чвыр 1977: 45) and in the Surkhandarya Region of Uzbekistan they were called uy isirga - earrings of the dwelling (yurt), as the shape of the cupola resembles the traditional nomadic dwelling of Central Asian nomads (Фахретдинова 1988: 121).

On the territory of the then Emirate of Bukhara, earrings of simpler forms were also made. They usually consisted of a silver openwork bead that was decorated in the lower part with a pyramid made using the granulation technique at the bottom. In the upper part, there was usually a coral bead, separated by a ring decorated with granulation. The part over the bead was spirally wound with a filigree or smooth wire [P1. 7]. In the Surkhandarya Region, they called the central bead guzacha - nut. Other times, the openwork beads were encrusted with turquoise. In this case, they were called kozik isirga - peg earrings. Settled inhabitants used to drive pegs into the wall of the bride's room and hang wedding towels (kozik lungi) and other items from the dowry on them. In Samarkand, in dressing the bride, a lace was threaded through into the trousers with a fruit tree peg, which was to ensure the fertility of the young woman. In the 40-day period after the birth of the child, the most dangerous to the child and the mother, a fruit tree peg was driven as a protective amulet into the floor at the threshold of the room with the newborn baby (Фахретдинова 1988: 122).

\section{Conclusion}

The head ornaments of mokhi tillo, tilla bargak and gajak represent jewellery belonging to the set worn by the bride from the time of the wedding and until the birth of the first child. After the birth of the offspring, it was permissible to wear only one jewel from this set, usually only on festive occasions. By contrast, the earrings were worn since early childhood. The first earrings were given to the baby as a gift by her father, mostly when she was 3-4 years old (Чвыр 1977: 92).

The forms of jewellery and their decorative elements as well as the preserved names themselves point to many motifs with specific meanings. In the mokhi tillo headdress ornament, tilla bargak diadem and the gajak pendants, we primarily identify fertility motifs (moon, birds, horse hoof etc.), which were to assure their bearers numerous offspring. For this reason, they were worn only by brides and young women. In the case of earrings, it was primarily an amulet to protect against evil forces and therefore given 
as such to newborns and small children that were the most endangered.

Not only the motifs, but the materials themselves from which the jewellery was made were significant amulets. In Central Asia, strong protective power was believed to be associated primarily with silver, but also with various kinds of gemstones such as turquoise, coral and carnelian.

\section{Acknowledgements:}

Translated by Radek Vantuch. Photographs by Jiří Vaněk. 


\section{Literature:}

Абдулдаев, Тургун А. - Фахретдинова, Деляра А.

1986 Песнь в метале: Народное искусство Узбекистана. Ташкент: Гафура Гуляма;

Богословская, Ирина - Девтеева, Дариса

2006 Тюбетейки Узбекистана XIX - XX веков. Ташкент: Мега Басим;

Борозна, Н. Г.

1975 “Некоторые материалы об амулетах - украшениях населения Средней Азии”, in: Снесарев, Глеб Павлович - Басилов, Владимир Николаевич (отв. ред.): Домусульманские верования и обрядь в Средней Азии. Москва, рр. 281-297;

Hejzlarová, Tereza

2007 "Pán a vládce stepi. Kůň v kulturách kočovníků Střední Asie”, in: Obuchová, Lubica: Lidé a zvîrata: soubor pracovní skupiny Člověk a krajina v dějinách. Praha: Česká orientalistická společnost, pp. 87-111;

Hejzlarová, Tereza - Pospíšilová, Dagmar

2012 Czech Travelers and Collectors in Central Asia (from the collection of the Náprstek Museum). Prague: National Museum;

Скреминская, Дюбовь

2017 “Эммануил Файт - Чешский исследователь Средней Азии”, in: Kulturní studia 1, pp. 31-38;

\section{Сухарева, Ольга Александровна}

1953 “К истории художественного ремесла в Узбекистане”, in: Толстов, Сергей Павлович (отв. ред.): Сборник Музея антропологии и этнографии XIV, pp. 119-139;

1982 История среднеазиатского костюма: Самарканд (2я половина ХІХ-начало ХХ в.).

Москва: Наука;

\section{Сычева Наталья С.}

1984 Ювелирные украшения народов Средней Азии и Казахстана ХІХ - ХХ веков.

Москва: Советский художник;

Тохтабаева, Шайзада Жаппаровна

1991 “Семантика казахских украшений", in: Советская этнография 1, pp. 90-102;

Фахретдинова, Деляра Ахатовна

1988 Ювелирное искусство Узбекистана. Ташкент: Издательство литературы и искусства;

\section{Чепелевецкая, Гертруда Дьвовна}

1961 Сузани Узбекистана. Ташкент: Гослитиздат УзССР;

\section{Чвырь, Людмила Анатольевна}

1970 “Отражение возрастных градаций в таджикских ювелирных украшениях", in: Советская этнография 4, рр. 115-121;

1972 “Ювелиры-ремесленники и местная художественная традиция в Таджикистане“, іп: Советская этнография 1, рр. 39-51;

1977 Таджикские ювелирные украшения. Москва: Наука. 


\section{Internet Resources:}

\section{Гюль, Эльмира}

2003 Ювелирное искусство Бухары (к семантике форм). San'at 4

- http://www.sanat.orexca.com/rus/archive/4-03/history_art6.shtml [15 May 2018];

\section{Дунева, Валентина}

2005 Из истории головных украшений Узбекистана. San>at 3,4

- http://www.sanat.orexca.com/rus/archive/3-4-05/from-history.shtml [15 May 2018];

\section{Наршахи, Мухаммад}

1897 История Бухары

- http://www.vostlit.info/Texts/rus12/Narsachi/pred.phtml?id=970 [15 May 2018];

\section{Дивана-и-Машраб}

Жизнеописание популярнейшего представителя мистицизма Туркестанском крае [online] / пер. с тюрк. Н.С. Лыкошина; изд. Самаркандского областного статистического комитета. Самарканд: Типодитография тов-ва «Б. А. Газаров», 1915 - http://oldbook.megacampus.com/index.html\#!go=part-1093/page.htm\&go=part-1093/ page.htm [15 May 2018].

Table of content measurements of Uzbek head ornaments. ${ }^{14}$

\begin{tabular}{|l|c|c|c|c|c|c|c|l|}
\hline & $\mathrm{Ni}$ & $\mathrm{Zn}$ & $\mathrm{Cu}$ & $\mathrm{Fe}$ & $\mathrm{Ag}$ & $\mathrm{Pb}$ & $\mathrm{Au}$ & Notes \\
\hline $\mathbf{2 1 2 2 9 - 1}$ & - & 0.3 & 4.5 & 0.1 & 94.9 & 0.2 & - & silver \\
\hline $\mathbf{2 1 2 2 9 - 2}$ & - & 0.2 & 7.2 & - & 91.9 & 0.6 & - & silver \\
\hline $\mathbf{4 0 4 0 8 - 1}$ & - & 0.3 & 2.2 & 0.2 & 97.3 & 0.1 & - & silver \\
\hline $\mathbf{4 0 4 0 8 - 2}$ & - & - & 1.2 & 0.1 & 66.8 & 0.5 & 31.3 & detail, silver-gilt \\
\hline $\mathbf{4 0 4 0 8 - 3}$ & - & - & 1.1 & 0.1 & 98.7 & 0.1 & - & pendant, silver \\
\hline $\mathbf{4 0 4 1 0}$ & - & - & 0.1 & 0.4 & 90.8 & 0.3 & 8.3 & silver-gilt \\
\hline $\mathbf{4 3 8 1 6}$ & - & 0.6 & 3.4 & - & 95.9 & 0.1 & - & silver \\
\hline A 15424-1 & - & - & 1.9 & - & 70 & - & 28 & silver-gilt (contains mercury) \\
\hline A 15424-2 & - & - & 5.9 & 0.1 & 93.8 & 0.1 & - & wire, silver \\
\hline A 18437-1 & - & 0.2 & 4.6 & - & 95.1 & - & - & silver (contains a small amount of gold) \\
\hline A 18437-2 & - & - & 8.4 & 0.1 & 91.4 & 0.1 & - & wire, silver \\
\hline A 18437-3 & 0.1 & 0.4 & 13.3 & 0.1 & 83.1 & - & 2.9 & pendant, silver-gilt \\
\hline A 28934 & - & - & 0.2 & - & 99.8 & - & - & silver \\
\hline
\end{tabular}

\footnotetext{
14 Hejzlarová - Pospíšilová 2012: 91.
} 


\section{Catalogue}

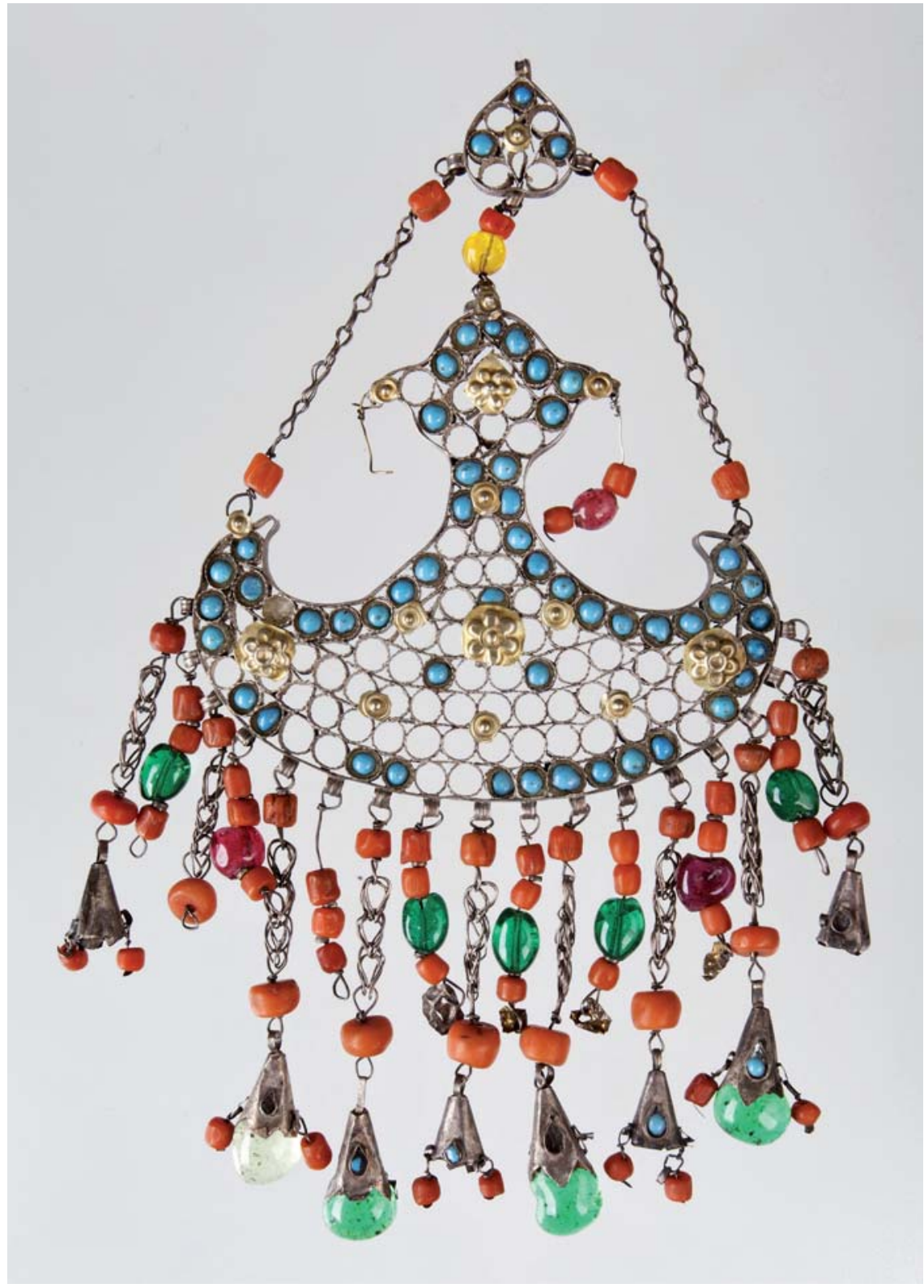

是

Pl. 1

Mokhi tillo headdress ornament

Uzbekistan, Samarkand.Around 1900

Silver, silver-gilt appliqué, filigree, glass, red coral, $1.15 .5 \mathrm{~cm}, \mathrm{w} .8 \mathrm{~cm}$.

Inv. No. 40408 Collection of Emanuel Fait, 1902, acquired 1950. Analogies: Чвыр 1977: 130, Fig. No. 8/3. 


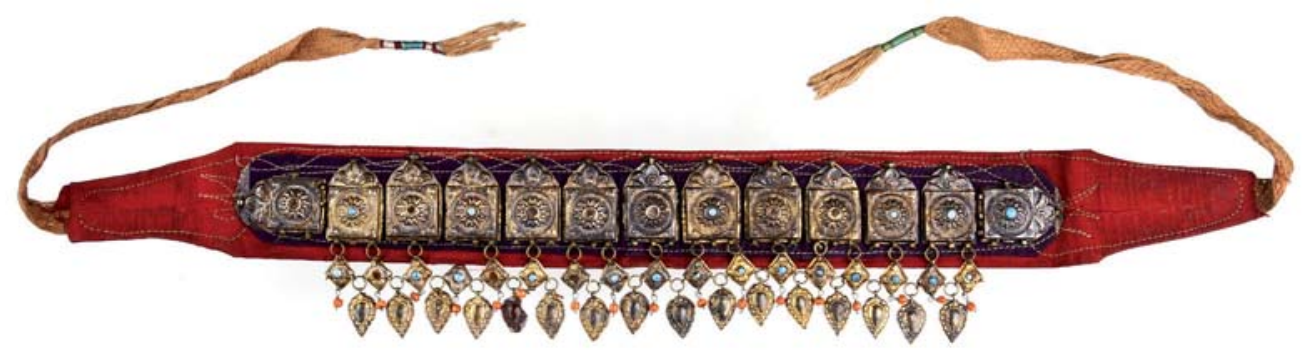

Pl. 2

Tilla bargak diadem

Uzbekistan, Samarkand. Around 1900

Silver-gilt, stamping, red coral, turquoise, h. $4.8 \mathrm{~cm}, 1.48 \mathrm{~cm}$

Inv. No. 40410. Collection of Emanuel Fait, 1902, acquired 1950. Analogies: Чвыр 1977: 130, Fig. No. 8/4, 8 .

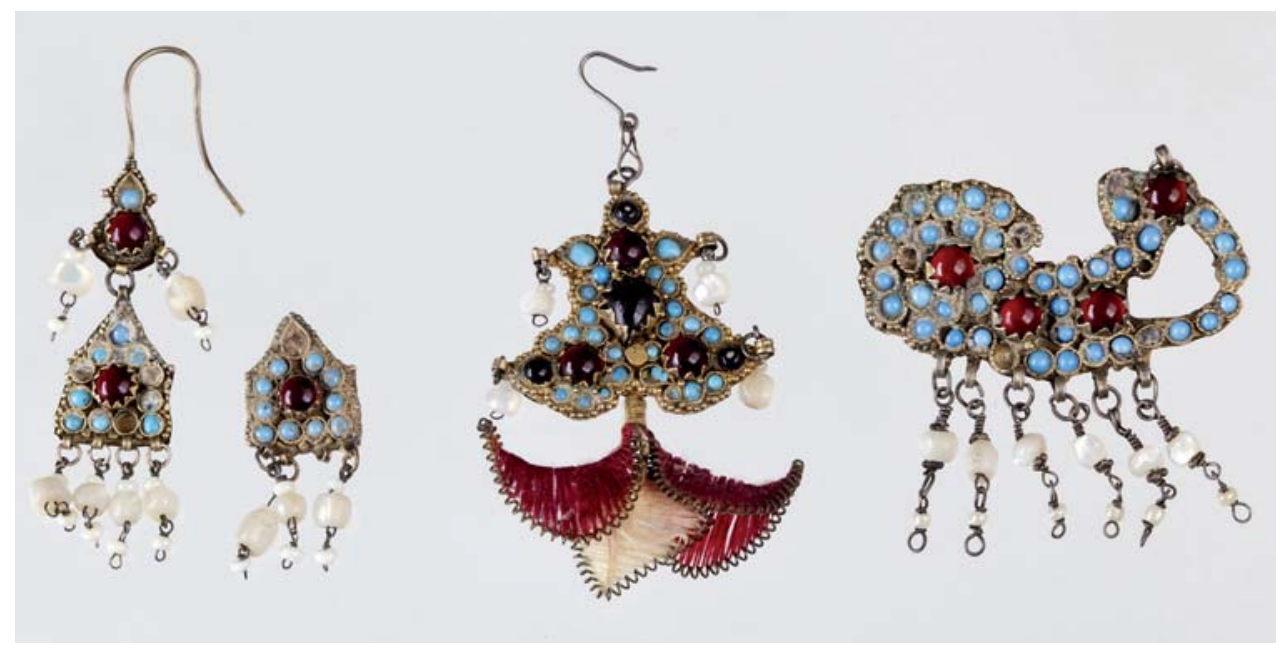

Pl. 3

Gajak and earrings (pendants)

Uzbekistan, Tashkent. Late $19^{\text {th }}$ century

Silver, granulation, stamping, glass, turquoise (imitation), $4.5 \times 4.5 \mathrm{~cm}, 7 \times 3 \mathrm{~cm}, 3.3 \times 1.5 \mathrm{~cm}$. Inv. Nos. A 28934/1-3 Collection of Emanuel Meergans, 1883. Analogies: Фахретдинова 1988, p. 98, 113, 115, Сычева 1984, Fig. No. 4. 

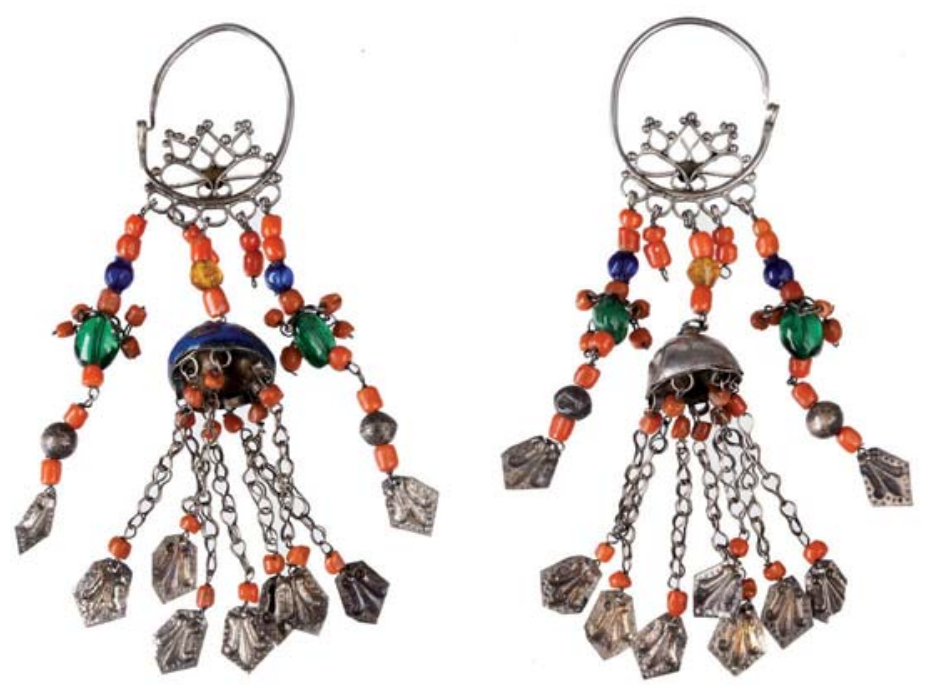

Pl. 4

Khalka earrings

Uzbekistan, Samarkand. Late $19^{\text {th }}$ century. Silver, filigree, stamping, glass, red coral, $1.10 \mathrm{~cm}$.

Inv. Nos. 21229 - 21 230. Collection of Václav Kračmer, 1891. Analogies: Чвыр 1977, p. 131, Fig. No. 9/2, Фахретдинова 1988, p. 121.
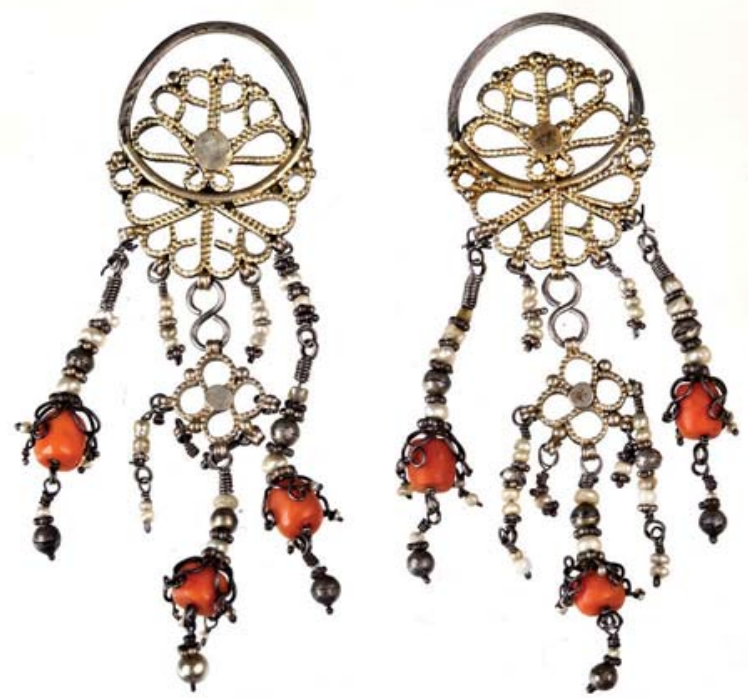

Pl. 5

Khalka earrings

Uzbekistan, Bukhara. Late $19^{\text {th }}$ - early $20^{\text {th }}$ century. Silver-gilt, filigree, red coral, pearls, $1.6 .8 \mathrm{~cm}$, w. $2.3 \mathrm{~cm}$.

Inv. No. A 15424 ab. Acquired 1985. Analogies: Чвыр 1977, p. 135, fig. no. 13/3. 


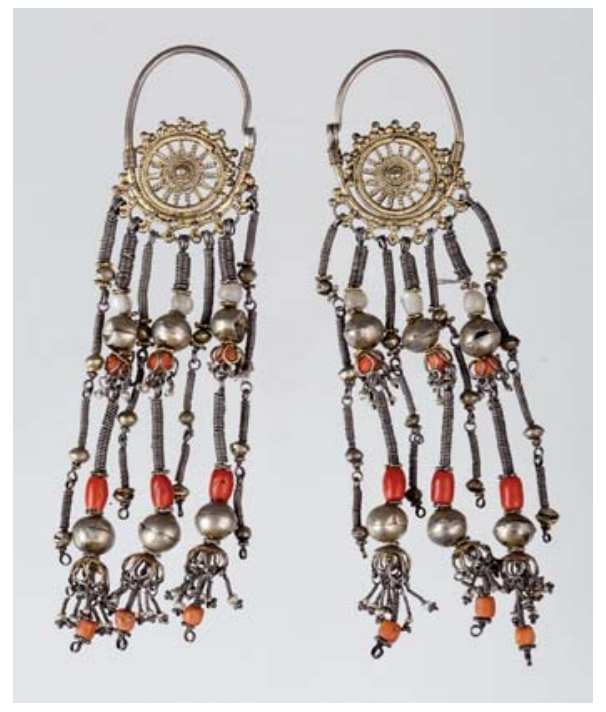

Pl. 6

Khalka earrings

Uzbekistan, Bukhara or Tashkent. Early $20^{\text {th }}$ century. Silver-gilt, filigree, granulation, red coral, glass, $1.11 .2 \mathrm{~cm}$.

Inv. No. A 18437 ab. Acquired 1987. Analogies: Чвыр 1977, p. 135, Fig. No. 13/1, 11, Абдуллаев, Фахретдинова 1986, Fig. No. 148.

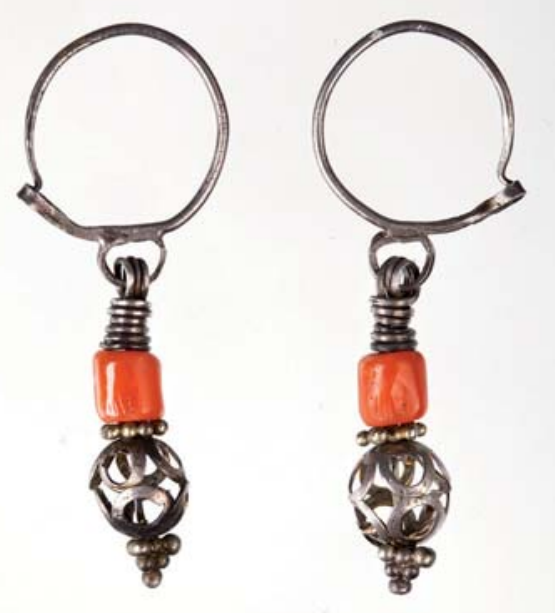

\section{Pl. 7}

Isirga (kozik isirga type)

Uzbekistan, Samarkand. Around 1900. Silver, granulation, openwork, red coral, $1.3 .9 \mathrm{~cm}$. Inv. No. 43816 ab. Collection of Václav Kračmer, 1902. Analogies: Фахретдинова 1988, p. 122. 